\title{
Response of some wheat genotypes to different salinity levels of Irrigated water
}

\author{
Soleman M. Al-Otayk
}

\author{
Department of Plant Production and Protection-College of Agriculture and Veterinary Medicine, \\ Qassim University, Buridah, Qassim, 51452, The Kingdom of Saudi Arabia
}

\author{
*Corresponding author: sole_2000@yahoo.com
}

\begin{abstract}
Salinity is one of the major constraints for crop production across the world. Saudi Arabia is dominated with desert environment with high salinity in the central region of the country. Therefore, salinity has a limiting factor for cereal crops in this region. The objective of this study was to assess the productivity and quality characters for some wheat (Triticum aestivum L) genotypes under different salinity levels of Irrigated water (control, 4000, 8000 ppm NaCl). The experiment was conducted during 2011 and 2012 seasons. The trial was conducted under greenhouse environmental condition at Qassim University Agricultural Research and Experimental Station during 2011 and 2012 seasons. Twenty wheat genotypes including: 5 genotypes from ICARDA, 7 genotypes from Pakistan, 5 Australian genotypes, one American genotype (Yocora Rojo), one Egyptian genotype (Sakha 93) and one local genotype (Sama) were used in this study. Results from wheat genotype trial showed a significant difference $(p<0.05)$ for all traits due to increased salinity in irrigation water from 4000 to $8000 \mathrm{ppm}$. There was a significant difference between the varieties for plant height, 1000-kernel weight, number of kernels spike $^{-1}$ and $\mathrm{Na}$ for grain and straw. The interaction effect was significant in number of spikes, 1000-kernel weight and Na for grain and hay and $\mathrm{Na} / \mathrm{K}$ cereal. The results showed that Auqab 2000, Bhan 2000 and Shaka 93 have the highest yield at high level of salt and Sis 13, P2 and Local were the least in yield. Moreover, the results of principle component analysis (PCA) indicated that the superior wheat genotypes for grain yield under salt stress in the two seasons (Auqab 2000, Bhan 2000, Yocara Rojo and Sakha 93) are clustered in group D. These genotypes can be considered as salinity resistant varieties. The maximum reduction over control under salt stress was recorded in Australian genotypes (P6 and P9) and local genotype 'Sama'.
\end{abstract}

Keywords: Wheat genotypes, salinity levels, $\mathrm{Na} / \mathrm{K}$, grain yield.

Introduction

Salt is one of the main problems that impact farmers all over the world. It increases rapidly with the use of more fresh water for domestic use and less fresh water available for agriculture (Ghassemi et al., 1995). Increasing salt in soil can destroy the crops totally and leave the land unproductive. Wheat (Triticum aestivum L.) is one of most important crop plants worldwide with annual production of about 736 million metric tons (FAO 2015), but suffers significant grain yield losses due to soil salinity. Although, there are several ways that can be used to amend the soil, the cultivation of salt tolerance varieties is recognized as the most effective way to overcome these limitations (Thalji and Shalaldeh, 2007). The researchers started earlier to find genetic variations for salt tolerant for different crops (Khan et al., 2005; Panahi et al., 2006). Wheat exhibits such variation (Goudarzi and Pakniyat, 2008), so it is possible to identify such tolerant varieties by using an appropriate screening procedure.

There are different methods that have been used to identify tolerant cultivars such as hydroponics (Khan et al., 2009) and using by field experiments (Panahi et al., 2006; Ahmed et al.,
2005). Shahzad et al. (2012) evaluated 44 wheat genotypes grown in Hoagland's hydroponic nutrient solution under $250 \mathrm{mM} \mathrm{NaCl}$ stress. They suggested that number of tillers per plant, root length, root fresh and dry weights, and shoot fresh and dry weights are associated with salt tolerance and could be used as selection criteria. In addition, there are many traits that can be taken to measure salt tolerance like grain yield (Thalji and Shalaldeh, 2007) and also many different physiological trait like $\mathrm{Na}+$ and $\mathrm{K}+$ (Khan et al., 2009). Munns and James (2003) considered biomass yield as a useful criterion because it permits the direct estimation of economic return under saline conditions. Tolerance to salt stress is a complex biological phenomenon governed by several physiological and genetic factors (Haq et al., 2010). The tolerant wheat genotypes possessed better ability to maintain stable osmotic potential, low $\mathrm{Na}+$ accumulation, higher shoot $\mathrm{K}+$ concentrations, maximal photochemical efficiency and low non-photochemical quenching, resulting in the higher dry matter production observed under salt stress (Oyiga et al., 2016). 
The horizontal expansion of agriculture in Al-Qassim region has led to salinity problem at both soil and water. The level of salinity in these areas is ranged from 2000 to 5000 ppm, which forms an obstacle to grow crops that are sensitive to salinity of irrigation water. Thus, several studies have been conducted to investigate the response of some filed crops such as wheat (Triticum aestivum L.) to salinity stress in arid and semi-arid regions (Pessarakli, 1999). Wheat is considered less tolerant to salinity comparing to other field crops. A study found that there is a significant difference on the impact of salinity on wheat leaf area and fresh and dry weight on the roots and shoots in Egypt (Tammam et al., 2008). The objectives of this research were to identify wheat cultivars that tolerance to salinity using greenhouse experiment and to identify salt level that will give maximum variation in grain yield.

\section{Results}

Results of the twenty wheat genotypes presented in Table 3 showed that there was a variation in some parameters. Analysis of variance shows that there are significant differences $(p<0.05)$ for all traits due to increased salinity in irrigation water from 2000 to 8000 ppm (Table 3). There was a significant difference between the varieties for plant height, 1000-grains weight, number of kernels spike-1 and $\mathrm{Na}$ of grains. Interaction was significant for grain yield in both seasons, number of spikes, $\mathrm{Na}$ of grains and $\mathrm{K} / \mathrm{Na}$ ratio in the first season, and number of kernels spike- 1 and 1000 grains weight in the second season.

\section{Grain yield}

Grain yield of different wheat genotypes was significantly influenced by the salinity (Tables 2 and 3). Grain yield was gradually decreased as of salinity levels increased and the decline was at the level of 8000 ppm ranged between $54-99 \%$ and that the product can be observed. Auqab 2000 genotype showed minimum reduction ( 54 and $43 \%$ ) and was followed by Bhan 2000 genotype (68 and 53\%) and Sakha 93 genotype (70 and $47 \%$ ) in both seasons, respectively (Tables 4 and 5). These genotypes (Auqab 2000, Bhan 2000 and Sakha 93) can be considered as salinity resistant varieties. Contrarily, the maximum reduction (88\%) over control was recorded in local genotype 'Sama' and Australian genotypes (P6 and P9) in the first season.

\section{Number of tillers per $\mathrm{m}^{-2}$}

Data concerning number of tillers $m-2$ is shown in Tables 2 and 3. Analysis of the data revealed that tillers $\mathrm{m}^{-2}$ was significantly ( $p<0.05$ ) affected by different genotypes, salt treatments, in both seasons and their interaction in the first season. Mean values of the data revealed that productive tillers $\mathrm{m}^{-2}$ were less (13.2 and 14), when wheat genotypes were sown at 8000 ppm salt treatment. When interaction between genotype and salt treatments was considered in the first season, the data indicated that maximum productive tillers $\mathrm{m}^{-2}$ (27.3 and 22.7) were produced by ICARDA genotype (IC 15) and local genotype 'Sama', respectively at control treatment (Fig. 1). The minimum productive tillers $\mathrm{m}^{-2}$ of these genotypes was noted at 8000 ppm salt treatment. However, genotypes Yocara Rojo, Sakha 93 and Auqab 2000 produced the maximum tillers $\mathrm{m}^{-2}$ at 8000 ppm salt treatment (Fig. 1).

\section{Number of kernels per spike}

Data regarding number of kernels spike ${ }^{-1}$ is indicated in Tables 2 and 3 . The data showed that number of kernels spike ${ }^{-1}$ was significantly $(p<0.05)$ affected by wheat genotypes, salt treatments, in both seasons and their interaction in the second season. Number of kernels spike ${ }^{-1}$ decreased with increase in salinity levels. Maximum number of kernels spike ${ }^{-1}$ (13.1 and 14.5) was observed in control treatment, compared with the other two salt treatments in both seasons, respectively. The maximum number of kernels spike ${ }^{-1}$ (12.2 and 18.9) was produced by genotype Bhan 2000 in both seasons, respectively. Interaction between genotype and salt treatments indicated that at higher salinity level ( $8000 \mathrm{ppm})$ the maximum number of kernels spike ${ }^{-1}$ (16.2 and 15.5) was produced by genotypes Bhan 2000 and Sakha 93, respectively (Table 6). The highest reduction in number of kernels spike ${ }^{-1}$ due to salinity over control was 72 and $73 \%$ in Australian genotype (P6) and local genotype (Sama), respectively.

\section{0 grains weight}

For 1000 grains weight, significant differences among genotypes, salt treatment and their interactions were detected (Tables 2 and 3). Salt stress significantly decreased 1000 grains weight by 48.9 and $55 \%$ in both seasons, respectively (Tables 2 and 3). The maximum 1000 grains weight of 30.1 and $34.9 \mathrm{gm}$ was produced by Australian genotype 'P2' and Pakistan genotype 'Bhan 2000' in the first and second season, respectively. Interaction between genotype and salt treatments indicated that maximum 1000 grains weight of 32.3 gm was produced at salt stress (8000 ppm) with Bhan 2000 in the second season (Table 7).

\section{Concentration of $\mathrm{Na}+\mathrm{K}+$ and $\mathrm{K}+/ \mathrm{Na}+$ ratio}

Salt treatments had significant effects on $\mathrm{Na}+, \mathrm{K}+$ and $\mathrm{K}+/ \mathrm{Na}+$ ratio of the wheat genotypes (Tables 2 and 3). $\mathrm{Na}$ concentration increased with increasing saline water salinity levels. Wheat genotypes responded differently to salt stress as well as between the salt treatments in the first season (Fig. 2). The salt treatments had insignificant effect on $K$ content of wheat genotypes, while $\mathrm{K}+/ \mathrm{Na}+$ ratio decreased under high salinity levels. In this study "Bhan 2000" had the lowest $\mathrm{Na}+$ content (23.9 and $17.6 \mathrm{ppm}$ ) and the highest $\mathrm{K}+/ \mathrm{Na}+$ ratio (1.48 and 2.28) in both seasons, respectively. Also, genotypes "Auqab 2000" and"Shakha 93", having higher $\mathrm{K}+/ \mathrm{Na}+$ ratio which may be considered as salt tolerant genotypes, while, Australian genotypes ( $\mathrm{P} 6$ and $\mathrm{P} 8$ ) gave the lowest $\mathrm{K}+/ \mathrm{Na}+$ ratio.

\section{Principle Component Analysis (PCA) of wheat genotypes}

The dendrogram was confirmed by PCA (Fig. 2). Wheat genotypes, in the PCA scatter plot (Fig. 3), indicated by the 
Table 1. List of the of the 20 wheat genotypes used in this study.

\begin{tabular}{llr}
\hline No & Genotype name & Genotype source \\
\hline 1 & Auqab 2000 & Pakistan \\
2 & Inq-91 & Pakistan \\
3 & Pas ban 90 & Pakistan \\
4 & Sis 13 & Pakistan \\
5 & Sis 32 & Pakistan \\
6 & Sis 27 & Pakistan \\
7 & Bhan 2000 & Pakistan \\
8 & P2 & Australia \\
9 & P6 & Australia \\
10 & P7 & Australia \\
11 & P8 & Australia \\
12 & P9 & Australia \\
13 & IC1 1 ICARDA \\
14 & IC15 & ICARDA \\
15 & IC16 17 & ICARDA \\
16 & IC17 & ICARDA \\
17 & IC 96 & ICARDA \\
18 & Sakha 93 & Egypt \\
19 & $*$ YR & USA \\
20 & $* *$ Sama & Saudi Arabia \\
\hline
\end{tabular}

* Yocora Rojo: - commercial genotype grows commonly in Saudi Arabia ** Sama: local genotype.

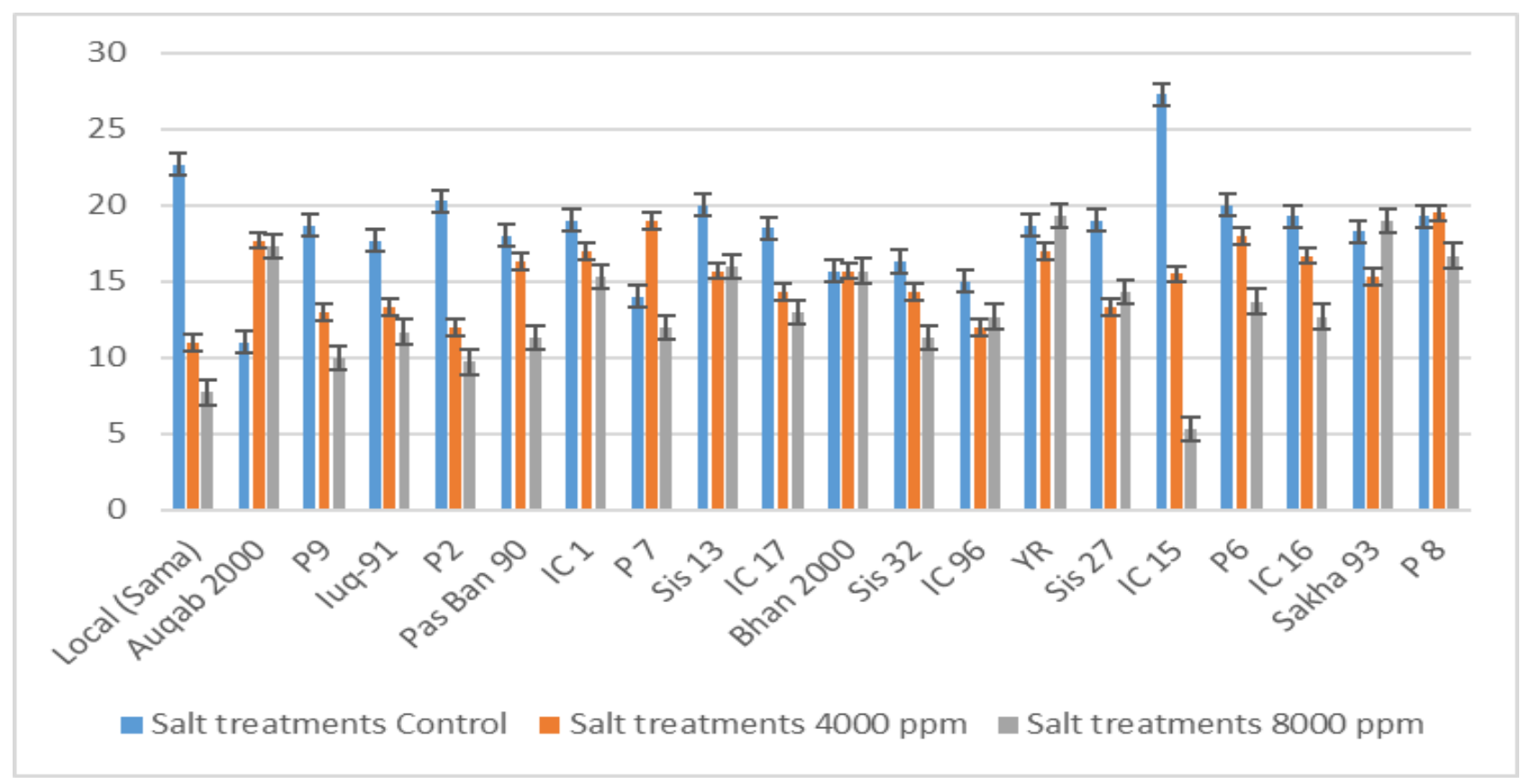

Fig 1. The interaction between wheat genotypes and salt treatments for number of spikes $\mathrm{m}^{-2}$ in $1^{\text {st }}$ season. 
Table 2. The effect of salt treatments and wheat genotypes on grain yield (GY), straw yield, number of spikes per $\mathrm{m}^{2}, \mathrm{kernels}^{\mathrm{s}} \mathrm{spike}{ }^{-1}$, 1000 -kernel weight, grain content of $\mathrm{Na}$ and $\mathrm{K}$, and $\mathrm{K} / \mathrm{Na}$ ratio in the first season.

\begin{tabular}{|c|c|c|c|c|c|c|c|}
\hline Treatments & Grain Yield $\left(\mathrm{gm} / \mathrm{m}^{2}\right)$ & $\begin{array}{l}\text { No. of spikes } \\
\text { per } \mathrm{m}^{2}\end{array}$ & $\begin{array}{l}\text { No. of kernels } \\
\text { per Spike }\end{array}$ & $\mathrm{Na}) \mathrm{ppm}($ & $\mathrm{K}(\mathrm{ppm})$ & $\begin{array}{l}1000 \text { grains } \\
\text { weight (gm) }\end{array}$ & $\mathrm{K} / \mathrm{Na}$ \\
\hline \multicolumn{8}{|c|}{ Salt treatments } \\
\hline Control & 9.7 & 18.4 & 13.1 & 8.5 & 31.1 & 32.3 & 2.99 \\
\hline 4000 ppm & 1.7 & 15.3 & 6.9 & 56.1 & 36 & 18 & 0.74 \\
\hline 8000 ppm & 1.2 & 13.2 & 4.9 & 75.4 & 37.2 & 16.5 & 0.53 \\
\hline LSD & 0.7 & 4.2 & 4.8 & 12.8 & 8.4 & 8.4 & 0.42 \\
\hline \multicolumn{8}{|c|}{ Wheat Genotypes } \\
\hline Local & 6.1 & 13.8 & 9.1 & 36 & 34.3 & 25 & 1.87 \\
\hline Auqab 2000 & 4.6 & 15.3 & 11.4 & 29.7 & 30.9 & 21.7 & 2.01 \\
\hline P9 & 3.8 & 13.9 & 6.8 & 52.2 & 36.1 & 23.6 & 1.94 \\
\hline luq-91 & 3.5 & 14.2 & 6.9 & 52.4 & 36.5 & 26.2 & 1.53 \\
\hline P2 & 4.4 & 14.0 & 6.6 & 47.1 & 34.3 & 30.1 & 1.81 \\
\hline Pas Ban 90 & 4.7 & 15.2 & 7.5 & 31.4 & 33.5 & 26.0 & 2.13 \\
\hline IC 1 & 5.7 & 17.1 & 10.6 & 48.9 & 33.3 & 22.4 & 1.44 \\
\hline P 7 & 4.2 & 15.0 & 9.8 & 33.7 & 33.6 & 18.4 & 2.41 \\
\hline Sis 13 & 4.4 & 17.2 & 8.1 & 57.7 & 35.9 & 19.7 & 2.03 \\
\hline IC 17 & 3.8 & 15.1 & 7.1 & 41.1 & 32.9 & 21.8 & 1.54 \\
\hline Bhan 2000 & 5.3 & 15.7 & 12.2 & 23.9 & 35.3 & 21 & 3.34 \\
\hline Sis 32 & 5.4 & 14 & 12.9 & 61.1 & 37.7 & 17.3 & 1.52 \\
\hline IC 96 & 3.1 & 13.2 & 7.5 & 46.6 & 34 & 21.8 & 1.52 \\
\hline YR & 3.9 & 18.3 & 9.3 & 31.4 & 34.9 & 19.2 & 0.93 \\
\hline Sis 27 & 3.8 & 15.6 & 7.7 & 37.4 & 34.7 & 23.3 & 0.87 \\
\hline IC 15 & 1.7 & 16.1 & 3.1 & 57.7 & 34.5 & 25.2 & 0.60 \\
\hline P6 & 3.0 & 17.2 & 6.3 & 54.7 & 34.1 & 19.6 & 0.70 \\
\hline IC 16 & 3.7 & 16.2 & 4.2 & 39.7 & 33.2 & 23.9 & 0.76 \\
\hline Sakha 93 & 4.4 & 17.6 & 10.4 & 33.9 & 35.2 & 19.0 & 0.89 \\
\hline P 8 & 3.8 & 18.4 & 8.2 & 50.9 & 34.1 & 22.8 & 0.7 \\
\hline LSD & 1.9 & 3.43 & 4.5 & 15.8 & 5.8 & 6.2 & 5.74 \\
\hline
\end{tabular}

The effect of salt treatments and wheat genotypes on grain yield (GY), straw yield, number of spikes per $\mathrm{m} 2$.

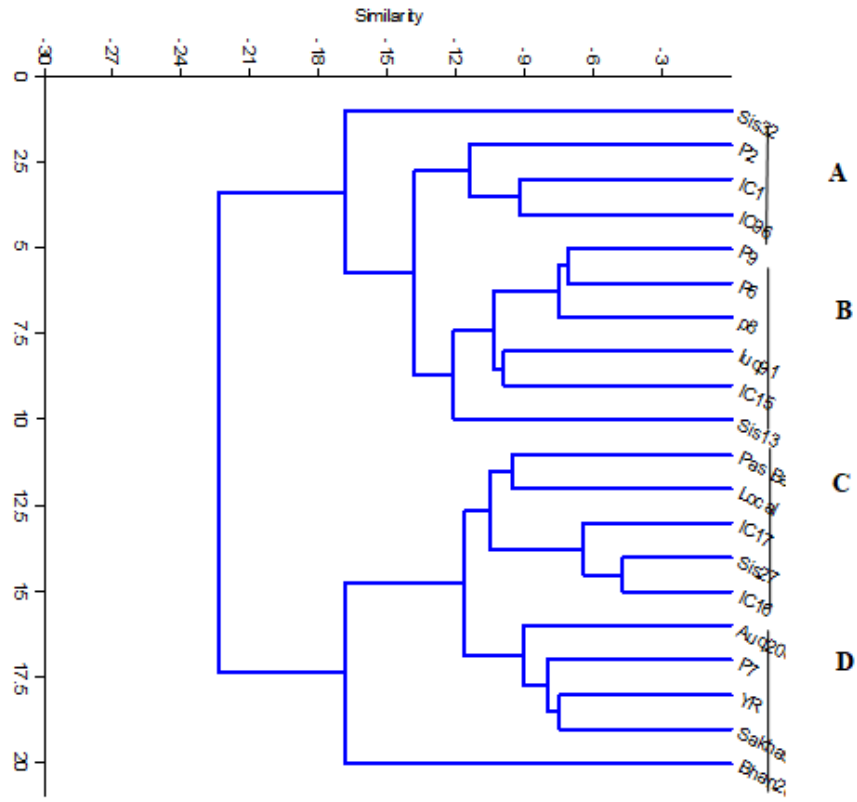

Fig 2. (UPGMA) dendrogram for 20 wheat genotypes. 
Table 3. The effect of salt treatments and wheat genotypes on grain yield (GY), straw yield, number of spikes per $\mathrm{m}^{2}$, kernels spike $^{-1}, 1000$-kernel weight, grain content of $\mathrm{Na}$ and $\mathrm{K}$, and $\mathrm{K} / \mathrm{Na}$ ratio in the second season.

\begin{tabular}{|c|c|c|c|c|c|c|c|}
\hline Treatments & $\begin{array}{c}\text { Grain Yield } \\
\left(\mathrm{gm} / \mathrm{m}^{2}\right)\end{array}$ & $\begin{array}{l}\text { No. of } \\
\text { spikes } \\
\text { per } \mathrm{m}^{2}\end{array}$ & $\begin{array}{c}\text { No. of } \\
\text { kernels } \\
\text { per Spike }\end{array}$ & $\begin{array}{c}\mathrm{Na} \\
(\mathrm{ppm})\end{array}$ & $\begin{array}{c}\mathrm{K} \\
(\mathrm{ppm})\end{array}$ & $\begin{array}{c}1000 \\
\text { grains } \\
\text { weight } \\
\text { (gm) }\end{array}$ & $\mathrm{K} / \mathrm{Na}$ \\
\hline \multicolumn{8}{|l|}{ Salt treatments } \\
\hline Control & 10.4 & 17.1 & 14.5 & 12.4 & 39.2 & 44.5 & 3.27 \\
\hline 4000 ppm & 4.3 & 17.1 & 11 & 28.4 & 42.9 & 22.4 & 1.62 \\
\hline 8000 ppm & 2.5 & 14 & 9 & 27.8 & 42.5 & 20 & 1.6 \\
\hline LSD & 3.02 & 3.8 & 1.6 & 4.74 & 25.6 & 11.0 & 1.86 \\
\hline \multicolumn{8}{|c|}{ Wheat Genotypes } \\
\hline Local & 7.7 & 21.3 & 9.6 & 21.8 & 40 & 26.8 & 2.27 \\
\hline Auqab 2000 & 5.9 & 13.1 & 13.4 & 20.4 & 39.8 & 33.5 & 2.16 \\
\hline P9 & 4.7 & 19.0 & 7.5 & 28 & 45 & 27.4 & 2.02 \\
\hline luq-91 & 6.5 & 15.9 & 14.3 & 23.3 & 40.1 & 27.5 & 1.93 \\
\hline $\mathrm{P} 2$ & 5.7 & 16.6 & 9.4 & 22.2 & 43.7 & 34 & 2.4 \\
\hline Pas Ban 90 & 5.1 & 14.8 & 11.6 & 24.6 & 40.9 & 27.7 & 2.05 \\
\hline IC 1 & 2.9 & 16.0 & 6.4 & 19.3 & 38.4 & 28.7 & 2.22 \\
\hline P 7 & 6.8 & 18.4 & 10.9 & 20.6 & 41.2 & 31.8 & 2.41 \\
\hline Sis 13 & 5.8 & 15.6 & 13.8 & 29.6 & 43.4 & 21 & 2.11 \\
\hline IC 17 & 5.9 & 15.1 & 11.8 & 22.2 & 42.2 & 33.4 & 2.29 \\
\hline Bhan 2000 & 8.9 & 13.1 & 18.9 & 17.6 & 39.9 & 34.9 & 2.67 \\
\hline Sis 32 & 5.7 & 15.4 & 14.3 & 20.6 & 38.7 & 26.6 & 2.04 \\
\hline IC 96 & 4.8 & 15.4 & 8.6 & 21.9 & 43.9 & 29.8 & 2.21 \\
\hline YR & 6.0 & 15.2 & 13 & 19.4 & 41.9 & 26.1 & 2.31 \\
\hline Sis 27 & 4.3 & 13.8 & 10.6 & 23.7 & 41.7 & 29.7 & 2.14 \\
\hline IC 15 & 4.7 & 19.1 & 10.2 & 24.3 & 41.3 & 24.3 & 2.12 \\
\hline P6 & 4.9 & 16.9 & 8.6 & 28.4 & 42.6 & 27 & 1.86 \\
\hline IC 16 & 5.5 & 13.6 & 10.7 & 24.4 & 41.8 & 29.5 & 2.11 \\
\hline Sakha 93 & 7.1 & 14.1 & 15.9 & 19.4 & 41.7 & 32.2 & 2.27 \\
\hline P 8 & 6.1 & 19.3 & 9.4 & 25.2 & 42 & 29.6 & 1.78 \\
\hline$\overline{\mathrm{LSD}}$ & 2.0 & 3.6 & 3.15 & 6.0 & 4.13 & 6.4 & 0.48 \\
\hline
\end{tabular}

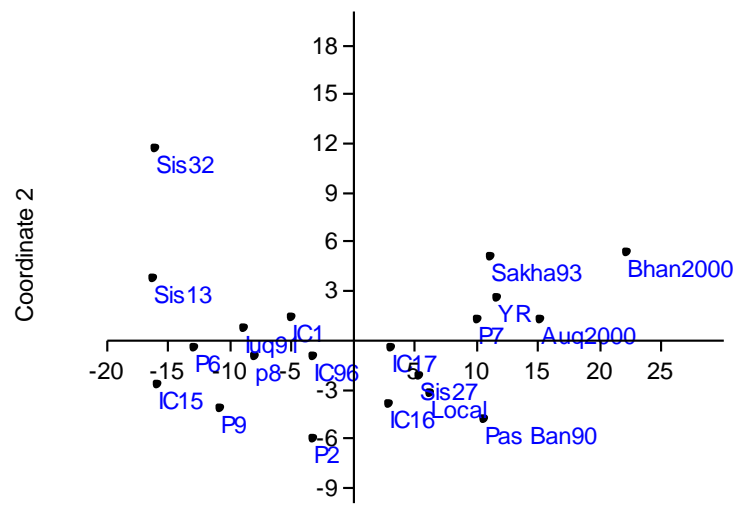

Coordinate 1

Fig 3. Principal component analysis (PCA) of the 20 wheat genotypes. 
Table 4. The interaction between wheat genotypes and salt treatments for grain yield in 1st season.

\begin{tabular}{rrllll}
\hline Genotypes & & Salt treatments & Reduction (\%) \\
\cline { 2 - 5 } & Control & $4000 \mathrm{ppm}$ & $8000 \mathrm{ppm}$ & \\
\hline Local (Sama) & 13.1 & 1 & 0.43 & 99 \\
Auqab 2000 & 5.5 & 2.87 & 2.53 & 54 \\
P9 & 8.4 & 1.03 & 0.7 & 92 \\
Iuq-91 & 6.4 & 1.2 & 1.03 & 81 \\
P2 & 9.4 & 0.83 & 0.5 & 95 \\
Pas Ban 90 & 7.3 & 1.73 & 1.5 & 79 \\
IC 1 & 11.3 & 1.7 & 1.4 & 88 \\
P 7 & 5.4 & 3.5 & 0.93 & 83 \\
Sis 13 & 9.2 & 1.37 & 0.43 & 95 \\
IC 17 & 12 & 1.13 & 0.9 & 92 \\
Bhan 2000 & 7.9 & 3.2 & 2.5 & 68 \\
Sis 32 & 11.6 & 1.37 & 0.67 & 94 \\
IC 96 & 4.7 & 1.67 & 0.7 & 85 \\
YR & 8.9 & 1.4 & 1.3 & 85 \\
Sis 27 & 9.1 & 1.43 & 0.83 & 91 \\
IC 15 & 3.6 & 0.75 & 0.5 & 86 \\
P6 & 6.7 & 1.03 & 1.15 & 83 \\
IC 16 & 6.6 & 1.17 & 0.63 & 90 \\
Sakha 93 & 6.5 & 2.2 & 1.97 & 70 \\
P 8 & 8.4 & 1.43 & 0.93 & 89 \\
LSD & 6.51 & & \\
\hline & & & & \\
\hline
\end{tabular}

Table 5. The interaction between wheat genotypes and salt treatments for grain yield in 2 nd season.

\begin{tabular}{rrrrr}
\hline Genotypes & \multicolumn{3}{c}{ Salt treatments } & Reduction (\%) \\
\cline { 2 - 4 } Local (Sama) & Control & $4000 \mathrm{ppm}$ & $8000 \mathrm{ppm}$ & 88 \\
Auqab 2000 & 15.7 & 6.1 & 1.8 & 43 \\
P9 & 8.1 & 5.1 & 4.6 & 82 \\
Iuq-91 & 10.5 & 2.1 & 1.9 & 67 \\
P2 & 11.6 & 4.1 & 3.6 & 77 \\
Pas Ban 90 & 11.5 & 3.6 & 2.6 & 86 \\
IC 1 & 10.1 & 3.1 & 1.4 & 67 \\
P 7 & 4.5 & 2.8 & 1.5 & 70 \\
Sis 13 & 11.5 & 5.3 & 3.4 & 85 \\
IC 17 & 11.9 & 3.8 & 1.8 & 86 \\
Bhan 2000 & 11.3 & 3.4 & 1.6 & 53 \\
Sis 32 & 13 & 8.1 & 6.1 & 56 \\
IC 96 & 9.5 & 4.3 & 4.2 & 93 \\
YR & 9.1 & 4.4 & 0.6 & 49 \\
Sis 27 & 7.8 & 6.8 & 4 & 67 \\
IC 15 & 7.3 & 3.2 & 2.4 & 76 \\
P6 & 9.7 & 3.3 & 2.3 & 91 \\
IC 16 & 9.7 & 2.6 & 0.9 & 87 \\
Sakha 93 & 13.1 & 2 & 1.7 & 47 \\
P 8 & 9.6 & 6.8 & 5.1 & 96 \\
\hline LSD & 11.9 & 5.1 & 0.5 & \\
\hline & & & & \\
\hline
\end{tabular}


Table 6. The interaction between wheat genotypes and salt treatments for number of kernels per spike in 2 nd season.

\begin{tabular}{rrrr}
\hline \multicolumn{3}{c}{ Senotypes } & \multicolumn{3}{c}{} \\
\cline { 2 - 5 } & Control & 4000 ppm & 8000 ppm \\
\hline Local (Sama) & 15.3 & 9.5 & 4.1 \\
Auqab 2000 & 13.8 & 14.1 & 12.2 \\
P9 & 10.8 & 7.1 & 4.5 \\
Iuq-91 & 18.2 & 12.1 & 12.6 \\
P2 & 15.5 & 7.9 & 4.9 \\
Pas Ban 90 & 14.2 & 8.1 & 12.4 \\
IC 1 & 6 & 7.1 & 6 \\
P 7 & 12.2 & 10.6 & 9.8 \\
Sis 13 & 19.4 & 11.9 & 10 \\
IC 17 & 16.6 & 7.6 & 11.1 \\
Bhan 2000 & 20.6 & 19.8 & 16.2 \\
Sis 32 & 12.7 & 17.1 & 13.2 \\
IC 96 & 10.2 & 11.1 & 4.5 \\
YR & 15.8 & 14.1 & 9.2 \\
Sis 27 & 12.4 & 12.8 & 6.5 \\
IC 15 & 16.8 & 6.9 & 6.9 \\
P6 & 13.7 & 6.6 & 3.9 \\
IC 16 & 15.3 & 7.2 & 9.5 \\
Sakha 93 & 16.1 & 16.2 & 15.5 \\
P 8 & 11.9 & 12.2 & 4.3 \\
LSD & & 10.77 & \\
\hline & & & \\
\hline & & & \\
\hline
\end{tabular}

Table 7. The interaction between wheat genotypes and salt treatments for weight of 1000 grains in 2 nd season.

\begin{tabular}{|c|c|c|c|}
\hline \multirow[t]{2}{*}{ Genotypes } & \multicolumn{3}{|l|}{ Salt treatments } \\
\hline & Control & $4000 \mathrm{ppm}$ & $8000 \mathrm{ppm}$ \\
\hline Local (Sama) & 44.6 & 21.3 & 16 \\
\hline Auqab 2000 & 46.6 & 20.6 & 21.8 \\
\hline P9 & 44.7 & 14 & 30.4 \\
\hline luq-91 & 44.3 & 19.6 & 16.2 \\
\hline $\mathrm{P} 2$ & 41 & 20.6 & 25 \\
\hline Pas Ban 90 & 46.2 & 23.1 & 13.1 \\
\hline IC 1 & 44.8 & 20.5 & 21.1 \\
\hline P 7 & 45.7 & 25.2 & 22.6 \\
\hline Sis 13 & 38.7 & 17.5 & 6 \\
\hline IC 17 & 52.3 & 23 & 22.6 \\
\hline Bhan 2000 & 43.3 & 30.8 & 32.3 \\
\hline Sis 32 & 46.6 & 20.2 & 12.9 \\
\hline IC 96 & 51.1 & 27.2 & 7.4 \\
\hline YR & 30.9 & 25.7 & 19.5 \\
\hline Sis 27 & 43.4 & 19.3 & 31.9 \\
\hline IC 15 & 38.2 & 27.7 & 12.5 \\
\hline P6 & 41 & 20 & 13.9 \\
\hline IC 16 & 53.9 & 19.1 & 15 \\
\hline Sakha 93 & 45 & 28.7 & 23.8 \\
\hline P 8 & 47.1 & 23.1 & 25 \\
\hline LSD & & 26.51 & \\
\hline
\end{tabular}


ellipses numbered with $A, B, C$, and D, seemed to form a very close grouping in the dendrogram (Fig. 2).

It is interesting that the superior genotypes for grain yield under salt stress in the two seasons (Auqab 2000, Bhan 2000, Yocara Rojo and Sakha 93) are clustered in group D (Fig. 2). These genotypes (Auqab 2000, Bhan 2000 and Sakha 93) can be considered as salinity resistant varieties.

\section{Discussion}

The studied wheat genotypes showed significant genetic variation for the traits measured. The grain yield was negatively affected by salt stress as already reported (Munns and Tester 2008, Rasheed 2009). Besides yield, yield components including kernels per spike, number of spikes $/ \mathrm{m}^{2}$, and 1000-grain weight have also been shown to be affected by salinity stress (Gholizadeh et al., 2014). The data showed that the genotypes (Auqab 2000, Bhan 2000 and Sakha 93) had the lowest $\mathrm{Na}+$ content and the highest $\mathrm{K}+/ \mathrm{Na}+$ ratio. The salt tolerance genotypes have the least amount of $\mathrm{Na}+$ in the seeds and high $\mathrm{K} / \mathrm{Na}$ ratio in the grains. The results are in agreement with the finding of (Goudarzi and Pakniyat, 2008; Tammam et al., 2008). They suggested that wheat crops with lowest $\mathrm{K}+/ \mathrm{Na}+$ ratio could be considered as non-tolerant cultivars under saline conditions. The increase in the shoot $\mathrm{K}+$ was accompanied by a significant decline in the shoot $\mathrm{Na}+$, showing antagonism between $\mathrm{K}+$ and $\mathrm{Na}+$ (Elhamid et al., 2014). Antagonism exits between $\mathrm{K}+$ and $\mathrm{Na}+$ in the site of ion uptake due to direct competition of both ions for absorption in the plants (Epstein 1966). The ionomics revealed that the tolerant genotypes had lower $\mathrm{Na}+$ and higher $\mathrm{K}+$ concentration than the sensitive ones. Salt-tolerant crops are characterized with higher affinity of $\mathrm{K}+$ over $\mathrm{Na}+$ uptake (Teakle and Tyerman 2010, Kausar et al. 2014). Joshi et al. (2010) concluded that no single parameter or group of parameters could be suggested as sole factor responsible for salinity stress tolerance of wheat genotypes. However, optimum $\mathrm{K}+/ \mathrm{Na}+$ ratio plays a vital role in maintaining an ideal osmotic and membrane potential for cell volume regulation in plant under salt stress and, has contributed to increase salt tolerance in wheat (El-Hendawy et al. 2009). Rodrigues et al. (2013) showed that the maximum rates of photosynthesis and plant growth occurred when the leaf $\mathrm{K} / \mathrm{Na}$ ratios were between 1.0 and 2.0 , indicating that this parameter could be a good indicator in leaves for favorable $\mathrm{K}+$ homeostasis under high-salinity conditions. Thus, the difference in salt tolerance among the three extreme genotypes (Auqab 2000, Bhan 2000 and Sakha 93) could be attributed to their $\mathrm{K}+/ \mathrm{Na}+$ discrimination ability associated with the machinery of water flow in plant under salt stress.

\section{Materials and Methods}

\section{Plant material and greenhouse experiment}

The experiment was conducted in 2011 and 2012 in a greenhouse environmental condition at the Qassim University Agricultural Research and Experimental Station. The average temperature of the greenhouse during the day was $28.5^{\circ} \mathrm{C}$. Wheat genotype included: five genotypes from International
Center for Agricultural Research in the Dry Areas (ICARDA), seven genotypes imported from Pakistan, five Australian genotypes, one American genotype (Yocora Rojo), one Egyptian genotype (Sakha 93) and one local genotype (Sama) (Table1). Two salinity levels of irrigated water (4000 and 8000 $\mathrm{ppm} \mathrm{NaCl}$ ) and a control were applied. Experimental design was a split plot design with three replications. The whole plots were salinity treatments, and subplots were wheat genotypes with three replications in each salinity treatment. After trial establishment, plants were mowed for the first time then the salinity treatments were applied at the concentrations indicated above.

\section{Data collection}

The agronomical studied characters of the wheat genotypes were: Earliness characters including number of spikes $\mathrm{m}^{-2}$, number of kernels spike-1, 1000-kernel weight, and grain yield. Grain yield was obtained from the four central rows to eliminate the border effect of each plot.

\section{Determination of $\mathrm{K}^{+}$and $\mathrm{Na}^{+}$concentrations}

Dry samples were weighted and wet digested using a mixture of $\mathrm{HNO} 3, \mathrm{H} 2 \mathrm{SO} 4$ and $\mathrm{HClO} 4$, and the $\mathrm{Na}^{+}$and $\mathrm{K}^{+}$concentrations in the digested solutions were determined using a flame photometer (Jenway PFP7), as described by AOAC (1990).

\section{Statistical analysis}

Data collected for agronomic and quality characters statistically analyzed according to the technique of analysis of variance (ANOVA). Coefficient of variation (CV) was listed to measure the precision of the experiment. All analyses of variance were computed using the MSTATC microcomputer program (MSTATC, 1990).

A principal Component analysis (PCA) was also carried out to show multiple dimensions of the distribution of the accessions in a scatter-plot using the PAST software version 1.62 (Hammer et al., 2001).

\section{References}

Ahmed A, Niazi, BH, Zaman B and Athar M (2005) Varietals differences in agronomic performance of six wheat varieties grown under saline field environment. Int J Environ Sci Tech. 2(1): 49-57.

AOAC (1990) Official methods of analysis of the Association of Official Analytical Chemists. AOAC, Arlington, VA, USA.

Elhamid EM, Sadak MS and Tawfik MM (2014) Alleviation of adverse effects of salt stress in wheat cultivars by foliar treatment with antioxidant 2-changes in some biochemical aspects, lipid peroxidation, antioxidant enzymes and amino acid contents. Agric Sci. 5: 1269-1280.

El-Hendawy S, Ruan Y, Hu Y and Schmidhalter U (2009) A comparison of screening criteria for salt tolerance in wheat under field and controlled environmental conditions. J Agron Crop Sci. 195: 356-367. 
Epstein E (1966) Dual pattern of ion absorption by plant cells and by plants. Nature 212: 1324-1327.

FAO (2015) FAO Cereal Supply and Demand Brief. http://www. fao.org/worldfoodsituation/csdb/en/ [last accessed 05 January 2016].

Ghassemi, F, Jakeman AJ and Nix HA. (1995) Salinization of Land and Water Resources. University of New South Wales Press Ltd., Canberra, Australia, pp. 562.

Gholizadeh A, Dehghania H and Dvorakb J. (2014) Determination of the most effective traits on wheat yield under saline stress. Agricultural Advances. 3: 103-110.

Goudarzi, M and Pakniyat, H. (2008) Evaluation of wheat cultivars under salinity stress based on some agronomic and physiological traits. J Agri Soc Sci. 4:35-38.

Hammer O, Harper DAT and Ryan PD. (2001) PAST: Paleontological Statistic software package for education and data analysis. Paleontologia Eletronica. 4(1): 1-9.

Haq TU, Gorham J, Akhtar J, Akhtar N, Steele KA (2010) Dynamic quantitative trait loci for salt stress components on chromosome 1 of rice. Funct Plant Biol. 37: 634-645.

Joshi A, Dang HQ, Vaid N and Tuteja, N. (2010) Pea lectin receptor-like kinase promotes high salinity stress tolerance in bacteria and expresses in response to stress in plant. Glycoconj J. 27:133-150.

Kausar A, Ashraf MY and Niaz M (2014) Some physiological and genetic determinants of salt tolerance in sorghum (Sorghum bicolor (L.) Moench): Biomass production and nitrogen metabolisim. Pakistan Journal of Botany. 46(2): 515-519.

Khan BA, Khan AN and Khan TH (2005) Effect of salinity on the germination of fourteen wheat cultivars. Gomal University Journal of research 21:31-33.

MSTATC (1990) A microcomputer program for the design. Management and analysis of agronomic Research experiments. Michigan State University, East Lansing, MI, USA.

Munns R, Tester M (2008) Mechanisms of salinity tolerance. Annual Review of Plant Biology. 59: 651-681.
Oyiga BC, Sharma R, Shen J, Baum M, Ogbonnaya F, Leon J and Ballvora A (2016) Identification and characterization of salt tolerance of wheat germplasm using a multivariable screening approach. Journal of Agronomy and Crop Science. 202(6):472-85.

Panahi M, Feizi M, Khayambashi B, Hajiakhondi H (2006) Saline condition and its effect on yield of nine durum wheat cultivars. Tenth International Water Technology Conference, IWTC10, Alexandria, Egypt.

Pessarakli M, Szabolcs I (1999) Soil salinity and sodicity as particular plant/crop stress factors. In: Pessarakli, ed. Handbook of Plant and Crop Stress, pp. 3-21. CRC Taylor and Francis Group, New York, NY, USA.

Rasheed R (2009) Salinity and extreme temperature effects on sprouting buds of sugarcane (Saccharum officinarum L.) Some histological and biochemical studies. Ph.D. thesis, Department of Botany, University of Agriculture, Faisalabad, Pakistan.

Rodrigues CRF, Silva EN, Ferreira-Silva SL, Voigt E, Viégas RA and Silveira JAG (2013) High K+ supply avoids $\mathrm{Na}+$ toxicity and improves photosynthesis by allowing favorable $\mathrm{K}+: \mathrm{Na}+$ ratios through the inhibition of $\mathrm{Na}+$ uptake and transport to the shoots of jatropha curcas plants. Journal of Plant Nutrition and Soil Science. 176: 157-164.

Shahzad A, Ahmad M, lqbal M, Ahmed I, Ali GM (2012) Evaluation of wheat landrace genotypes for salinity tolerance at vegetative stage by using morphological and molecular markers. Genet Mol Res. 11(1):679-692.

Tammam AA, Abou Alhamd MF, Hemeda MM (2008) Study of salt tolerance in wheat (Triticum aestivum L.) cultivar Banysoif 1. Aust J Crop Sci. 1 (3), 115-125.

Thalji T and Shalaldeh G (2007) Screening wheat and barley genotypes for salinity resistance. Journal of Agronomy. 6 (1):75-80

Teakle NL and Tyerman SD (2010) Mechanisms of Cl-transport contributing to salt tolerance. Plant Cell Environ. 33:566-589. 